\title{
TROCHODENDRACEOUS FRUITS AND FOLIAGE IN THE MIOCENE OF WESTERN NORTH AMERICA
}

\author{
STEVEN R. MANCHESTER ${ }^{1, *},{ }^{*}$ KATHLEEN B. PIGG ${ }^{2}$, MELANIE L. DEVORE ${ }^{3}$ \\ ${ }^{1}$ Florida Museum of Natural History, Dickinson Hall, 1659 Museum Road, Gainesville, Florida 32611-7800, USA; \\ e-mail: steven@flmnh.ufl.edu. \\ ${ }^{2}$ School of Life Sciences and Biodiversity Knowledge Integration Center (BioKIC), PO Box 874501, Arizona State University, Tempe, Arizona \\ 85287-4501, USA; e-mail: kpigg@asu.edu. \\ ${ }^{3}$ Department of Biological \& Environmental Sciences, Georgia College and State University, Milledgeville, GA 31061, USA; \\ e-mail: melanie.devore@gcsu.edu. \\ * corresponding author
}

Manchester, S. R., Pigg, K. B., DeVore, M. L. (2018): Trochodendraceous fruits and foliage in the Miocene of western North America. - Fossil Imprint, 74(1-2): 45-54, Praha. ISSN 2533-4050 (print), ISSN 2533-4069 (online).

\begin{abstract}
Two fossil fruit types and at least one fossil leaf type representing Trochodendraceae are recognized from the middle Miocene Cascadia flora of western Oregon, USA. Trochodendron rosayi sp. nov., known also from the middle Miocene of eastern Oregon and northern Idaho, is based on long-pedicelled, apically dehiscent capsular fruits with 7-9 persistent outcurved styles, very similar to the extant monotypic east Asian species T. aralioides. Concavistylon kvacekii gen. et sp. nov. is named for a racemose infructescence bearing shortly pedicellate, apically dehiscent capsules with 4 to 5 persistent incurved styles arising from the basal 1/3 of the fruit. Leaves associated at the Moose Mountain locality are recognized as Trochodendron postnastae sp. nov. They have basally acrodromous venation with a prominent midvein bracketed by a pair of strongly ascending basal secondaries and are thought to correspond to the T. rosayi fruits. These new occurrences demonstrate that greater diversity was present among fossil Trochodendraceae than previously recognized during the Miocene in western North America.
\end{abstract}

Key words: Fossil fruits, fossil leaves, Neogene, Oregon, McAbee flora, Republic flora, Tetracentron, Trochodendron, Trochodendraceae

Received: November 9, 2017 | Accepted: January 6, 2018 | Issued: August 31, 2018

\section{Introduction}

Trochodendron SIEBOLD et ZuCCARINI and Tetracentron OLIVER, constituting the only extant genera of the family Trochodendraceae (sensu APG III 2009), are both endemic to east Asia today, but have a long history in western North America from at least the early Eocene through the midMiocene. Trochodendron fruits and foliage and Tetracentron leaves have been recognized at several Eocene localities in the Okanogan Highlands (Greenwood et al. 2016), at and near the town of Republic, northeastern Washington, USA (Pigg et al. 2001, 2007) and at the McAbee locality near Cache Creek, in central British Columbia, Canada (Pigg et al. 2007). The Late Cretaceous to Miocene genus Nordenskioeldia HEER is also present as a rare element in the Eocene Okanogan flora (Pigg et al. 2001, Pigg and Wehr 2002). This extinct genus has been treated as a member of Trochodendraceae (Crane et al. 1991, Manchester et al. 1991), but this systematic placement has been challenged (Doweld 1998) and is in need of further investigation.
Younger records of Trochodendraceae occur in the Miocene of western North America, Iceland (Grímsson et al. 2008, Denk et al. 2011), Europe (Grímsson et al. 2015), Japan (Uemura 1988), and Kamchatka (Chelebaeva and Chigaeva 1988). North American occurrences include Trochodendron infructescences from the middle Miocene of Emerald Creek, Idaho, USA (Manchester et al. 1991) and Sucker Creek, Oregon, USA (Fields 1996a, b), although they were not assigned formally to species until now. A Tetracentron infructescence with pollen adhering to the stigmas was described from the middle Miocene of Clarkia, Idaho, USA (Manchester and Chen 2006), and isolated leaves, fruits and pollen of Tetracentron have been described from the Miocene of Iceland (Grímsson et al. 2008, Denk et al 2011). Fossil leaves of Tetracentron are known also from the Neogene of Japan (Tanai 1961, Suzuki 1967, Ozaki 1987).

Hergert and Phinney (1954) described the distinctive vesselless wood of Trochodendroxylon from the Oligocene Sweet Home flora in western Oregon and considered it to be anatomically more similar to Trochodendron than to 
Tetracentron, but the other organs associated with that plant have not been determined. In the present study, we describe trochodendraceous infructescences, fruits, and foliage collected from the middle Miocene Moose Mountain flora near Cascadia, Oregon. These fossils occur within the same stratigraphic sequence as the Trochodendroxylon wood of Hergert and Phinney (1954) (Little Butte Volcanic Series). The age of the Moose Mountain flora was previously considered early Miocene (Wolfe in Peck et al. 1964) or late Oligocene (Wolfe and Tanai 1987) based on floristic correlations, but we now consider it to be middle Miocene based on radiometric dating discussed below. We compare the Moose Mountain fossils to those known from other Cenozoic localities, as well as with the extant species, and consider the evolutionary and biogeographic implications.

\section{Material and methods}

Fossils were recovered from the Miocene Moose Mountain flora (Text-fig. 1), also referred to as the Menagerie Wilderness, or Cascadia flora, in Linn County, western Oregon (USGS locality 9350; UF locality 18110, $44^{\circ} 26.5790^{\prime} \mathrm{N}, 122^{\circ} 18.9570^{\prime} \mathrm{W}$ ). Collections were made by Eleanor Gordon Thompson in the 1950s (donated to University of California Museum of Paleontology, Berkeley - specimens with catalog numbers prefixed by UCMP). A floristic list was provided by Jack Wolfe (in Peck et al. 1964). More recent collections were made by Robert Rosé, who donated selected specimens to the Florida Museum of Natural History, Gainesville, Florida (specimens with catalog numbers prefixed by UF).

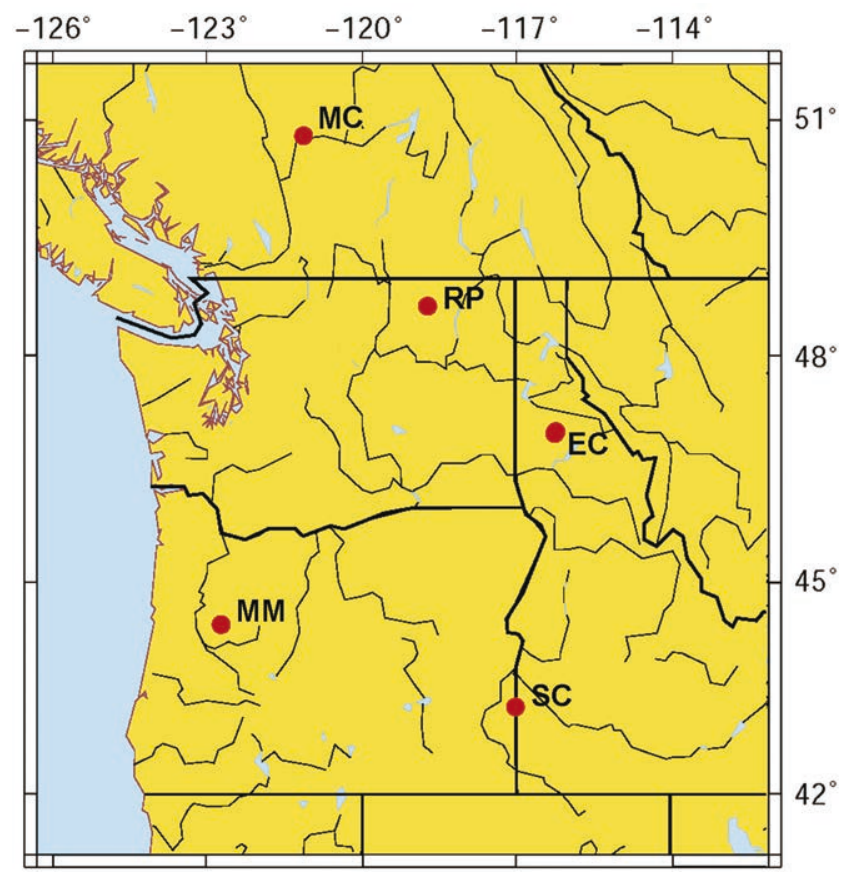

Text-fig. 1. Map of localities mentioned in the text. EC = Emerald Creek, Idaho, middle Miocene; MC = McAbee, British Columbia, early middle Eocene; $\mathrm{MM}=$ Moose Mountain, middle Miocene; RP = Republic, Washington, early middle Eocene; SC = Sucker Creek, Oregon, middle Miocene.
A middle Miocene age for the Moose Mountain flora was obtained based on plagioclase crystals extracted from a tuffaceous sandstone collected by Robert Rosé from the fossil-bearing horizon. The sample was dated by Robert Duncan using the 40Ar-39Ar incremental heating method in the Noble Gas Mass Spectrometry Laboratory at Oregon State University in 2011. The resulting age of $14.91 \pm 0.23$ $\mathrm{Ma}$ is the plateau age assessed from isotopic composition of Ar degassed in 12 temperature steps, from $400{ }^{\circ} \mathrm{C}$ to fusion at around $1400{ }^{\circ} \mathrm{C}$. Measurements were made with a MAP 215-50 gas mass spectrometer with all-metal extraction system equipped with a $10 \mathrm{~W} \mathrm{CO}_{2}$ laser connected to an ultra-clean, low volume $(\sim 1,000 \mathrm{cc})$ gas cleanup line. The associated isochron age, calculated without assumption about the initial Ar composition of the crystals, is nearly identical at $14.88 \pm 0.34 \mathrm{Ma}$. These ages were calculated relative to the standard monitor age of $28.030 \pm 0.003 \mathrm{Ma}$ for the Fish Canyon Tuff sanidine.

Specimens were photographed with low-oblique reflected light using a Canon Rebel digital camera with 60 $\mathrm{mm}$ macro lens. Additional images were obtained using microCT scanning X-ray data. The scanning of impression specimens in shale was performed at the University of Florida College of Engineering Nanoscale Research Facility with a GE Phoenix V|tome|xm240 CT Scanner, using a Tungsten reflection target and $0.5 \mathrm{~mm}$ copper filter, with a voltage of $210 \mathrm{kV}$ and current of $170 \mathrm{uA}$ with 2250 images of a single specimen for voxel size of $41 \mu \mathrm{m}$. Datasets reconstructed as tiff stacks from the micro-CT scans were analyzed with Avizo 9.0 Lite (FEI Visualization Science Group, Bordeaux, France) to generate isosurface renderings which were exported as Stanford Ply files, and examined with Meshlab (http://www.meshlab.net/).

Leaves are described following the terminology of Hickey (1973). Terminology for reproductive characters is as in Judd et al. (2007).

\section{Systematic palaeobotany}

Here we describe two fruit types, Trochodendron rosayi, and Concavistylon kvacekii, followed by the foliage species, T. postnastae. New names of fossil plants are registered in the Plant Fossil Names Registry, hosted and operated by the National Museum Prague for the International Organisation of Palaeobotany (IOP), each with a unique registry number.

\section{Infructescences}

Family Trochodendraceae Prantl, 1888

Genus Trochodendron Siebold et ZuCCARINI, 1838

Trochodendron rosayi sp. nov.

Text-fig. $2 \mathrm{a}-\mathrm{d}$

Holotype. UF 18110-70162 (Text-fig. 2b, c), designated here.

Plant Fossil Names Registry Number. PFN000100 (for new species).

E t y m o lo g y. This species is named in honor of Robert Rosé (pronounced "Rosay") who collected and donated the specimens. 

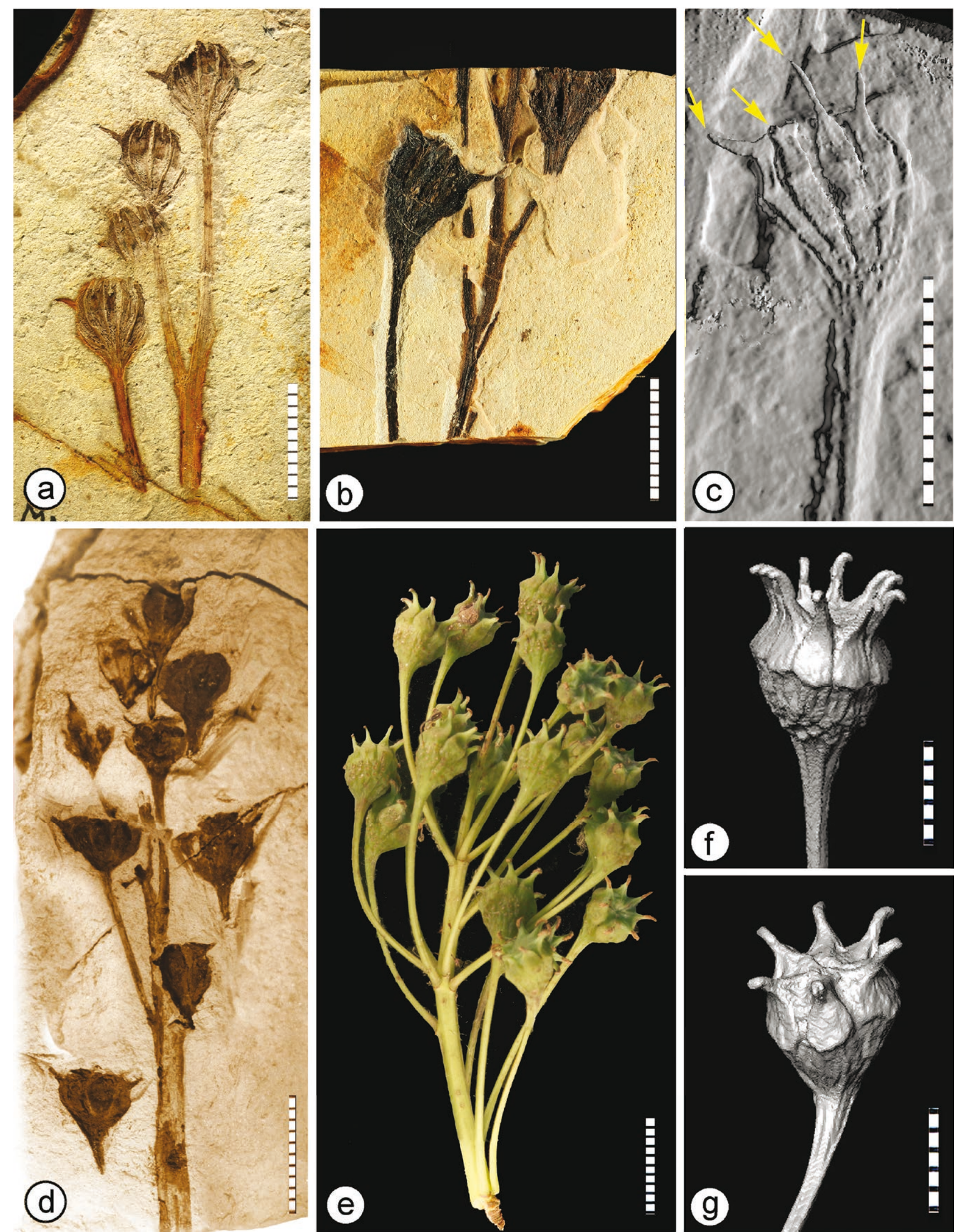

Text-fig. 2. Miocene and extant Trochodendron fruits. a-d) Trochodendron rosayi sp. nov. infructescences. a-c) Specimens from Moose Mountain flora, Oregon. a) Raceme bearing at least 4 fruits showing long pedicels, and outwardly protruding persistent styles, UF 18110-70164. b) Raceme showing two attached fruits and pedicels indicating at least 4 fruits, holotype, UF 18110-70162. c) Surface of one fruit of the holotype (UF 18110-70162), viewed through the sediment from behind from CT scan data. Arrows indicate 4 of the styles (more can be inferred from symmetry) each with a nectary beneath. d) Infructescence from Emerald Creek, Idaho; composite image assembled from images both incomplete counterpart specimens, reflected light, UF 18630-9575. e) Racemose infructescence of extant Trochodendron aralioides, reflected light. f, g) Individual fruits from (e), enlarged, isosurface images from CT scan data. Fruits with ten and six styles; note staminal scars seen in (f). Scale bars calibrated in mm. 
Type locality. Moose Mountain near Cascadia Oregon (UF locality $18110,44^{\circ} 26.5790^{\prime} \mathrm{N}, 122^{\circ} 18.9570^{\prime}$ W), USA.

Type horizon and age. Little Butte Volcanic Series, middle Miocene.

Additional oc currence. Emerald Creek, Idaho (Trochodendron sp. in Manchester et al. 1991), Sucker Creek, Oregon (Fields 1996a: pl. 3, figs 1, 3).

D i a g n o s is . Fruits turbinate to subglobose capsules, broadly rounded apically, tapered basally, with about 10 persistent styles arising about $2 / 3$ of the distance from base to apex. Styles straight to curving outward (convexly). Pedicels slender, ca. twice as long as the fruit length. Capsule surface mostly smooth, opening apically with radiating loculicidal slits, a slit arising above each style and joining with other slits to form a large, polygonal aperture at fruit apex when dehiscing. Nectaries flattened, triangular, extending from the equatorial region of the fruit to the base of each style. Stamen scars numerous (ca. 25 in total) scattered in a broad band at the junction between pedicel and expanded part of the fruit body.

Dimensions. Fruits $5.7 \mathrm{~mm}$ wide, $7.5-10 \mathrm{~mm}$ high, Styles 1.8-2.3 mm long, Nectary below each style ca. $1.5 \mathrm{~mm}$ wide, $2.0 \mathrm{~mm}$ high. Pedicels 1.0 to $1.2 \mathrm{~mm}$ thick and at least $18-20 \mathrm{~mm}$ long. Infructescence axis 1.8 to $2.0 \mathrm{~mm}$ thick.

R e $\mathrm{m}$ a r k s. We consider the rare specimens previously illustrated from Emerald Creek, Idaho (Text-fig. 2d; Manchester et al. 1991) and Sucker Creek, Oregon (Fields $1996 \mathrm{a}, \mathrm{b})$ to be conspecific with the type material from the Moose Mountain flora. Triangular flattened areas beneath each of the styles (Text-fig. 2c) are shaped and positioned like the nectaries in the extant species (Text-fig. 2f, g). Elliptical verrucae near the base of the fruit, imaged by $\mathrm{x}$-ray tomography of the holotype (Text-fig. 2c), appear to represent the scars of numerous shed stamens and are positioned as in extant fruits (Text-fig. 2f).

Trochodendron rosayi fruits are very similar to those of extant T. aralioides Siebold et ZucCarini (Text-fig. 2e-g), and apparently to the Miocene species Trochodendron kamtschaticum CHELEBAEva et CHIGAEva from Kamchatka and to the infructescence associated with leaves of $T$. protoaralioides MuRAI (Uemura 1988) from the late Miocene of Japan (Manchester et al. 1991: figs 30, 33). These Asian Miocene specimens have a similar size, shape and number of carpels but the persistent stamen scars were not confirmed.

It is instructive to compare $T$. rosayi with Trochodendron infructescences known from older strata of the Okanogan Highlands Eocene. Two infructescences from Republic described as Trochodendron sp. (Pigg et al. 2001) have pedicellate fruits of similar morphology, but the fruits are much smaller: $1.85-2.5 \mathrm{~mm}$ long and 2.0-3.7 mm wide. One isolated fruit figured in the same article, might represent a different taxon (Pigg et al. 2001: fig. 4H; K. Pigg, personal observation). The paniculate infructesence named $T$. drachukii Pigg, Dillhoff, DeVore et Wehr from McAbee (Pigg et al. 2007) bears fruits that are 3-4 mm long and wide and have 8 or more persistent styles. It has been difficult to determine whether those geologically older fruits bore nectaries beneath each style and whether there were staminal scars over the basal 1/3 of the fruits as in the modern species and in T. rosayi. Trochodendron rosayi thus differs from the Eocene fruits by the larger size, the direction of style curvature (straight to outward rather than inward) and the confirmed presence of stamen scars on the base of the fruits.

\section{Genus Concavistylon gen. nov.}

Ty p e. Concavistylon kvacekii sp. $\mathrm{n}$.

Plant Fossil Names Registry Number. PFN000101 (for new genus).

Diagnosis. Infructescence a spike or raceme with closely spaced, subsessile to short-pedicelled capsules. Raceme axis relatively stout. Capsules subglobose, rounded apically, with several persistent styles arising subequatorially, about $1 / 3$ of the distance from base toward apex; styles concave, directed toward the fruit apex. Capsule opening apically with radial dehiscence slits extending from immediately above each style to the fruit apex.

\section{Concavistylon kvacekii sp. nov. Text-fig. 3a-k}

\section{H o l o ty pe. UCMP 151875 (Text-fig. 3a).}

Plant Fossil Names Registry Number. PFN000102 (for new species).

Ety mology. This species is named in honor of our friend, Zlatko Kvaček, recognizing his many contributions to paleobotany as well as his participation in the investigation of other fossil Trochodendraceae from western North America.

Type locality. Moose Mountain flora near Cascadia, Oregon, USA.

Type horizon and age. Little Butte Volcanic Series, middle Miocene.

Diagnosis. Infructescence axis relatively stout, pedicels very short, or fruits subsessile. Capsules 4 to 6 carpellate; styles persistent, concave toward the fruit apex.

Dimensions. Raceme $1.3-1.8 \quad \mathrm{~mm}$ wide. Infructescence 40-51 mm long; capsules 3-4 $\mathrm{mm}$ high, 2.5-3.4 mm wide; styles $1.5-2 \mathrm{~mm}$ long, concave toward the fruit apex.

Remarks. Concavistylon is a new genus of infructescence with a combination of characters found separately in the two extant genera of Trochodendraceae, along with some unique features. The fruits are shortly pedicellate or subsessile, resembling Tetracentron which has sessile fruits. Unlike Tetracentron, which has four basal tepals that persist even to fruiting stage, these fruits appear to lack perianth, and in this respect resemble Trochodendron. The number of styles is small (4-5; Text-fig. $3 \mathrm{f}-\mathrm{k})$ as in Tetracentron (4) rather than more abundant (7-9 in Trochodendron). The dehiscence is apical by convergent loculicidal slits as in both extant genera. The distal displacement of the styles toward the edge of the gynoecium coincides with the development observed 



Text-fig. 3. Concavistylon kvacekii gen. et sp. nov. from Moose Mountain flora, Oregon. a) Infructescence reflected light, holotype, UCMP 151875. b) Digital profile of the same infructescence, CT scan data, viewed through the sediment (rendered transparent) from behind. c) Raceme with several fruits showing styles concave toward fruit apex, UCMP 201233. d) Raceme with stout axis, UCMP 201232. e) Long slender specimen, with fruits spaced farther apart, possibly immature, UCMP 201231. f) Detail from (c), showing persistent styles, light microscopy. g) Detail from (b), CT scan surface rendering. Note 5 styles arising from upper left fruit. h) Infructescence with at least 18 fruits, reflected light, UF 18110-70163. i) Same specimen as (a), (b), (g), imaged with depth map rendering, showing apically opening capsules and 5 apically directed styles on each fruit, (j) same as (h), isosurface from CT scan data, showing apical opening of capsules. $k)$ Depth map rendering of the specimen in $(\mathrm{h})$, (j). Scale bars $=1 \mathrm{~cm}$ in $(\mathrm{a}-\mathrm{e})$, (h-j); $5 \mathrm{~mm}$ in (f), (g).

in both modern genera (Endress 1986). However, the styles are curved inward toward the apex of the fruit, rather than turned outward as in Miocene and extant Tetracentron and Trochodendron species.

Infructescences that appear to represent Concavistylon are also known from the Eocene of Republic, Washington and McAbee, British Colombia but in those occurrences the pedicels are longer whereas the fruits of the Moose Mountain species are subsessile. One such specimen was previously identified as the extant genus (Manchester et al. 2009), but has been confirmed by CT scan to have fewer carpels (5-6) than modern Trochodendron. One specimen 
from Republic (Manchester et al. 2017) is particularly informative because it bears both fruits and foliage on the same twig, proving that a pinnately veined leaf type similar to that of modern $T$. aralioides was borne by the same plant as Concavistylon. Such leaves also occur at McAbee where several Concavistylon infructescences have been recovered. We expected that similar leaves might be common in the Miocene of Moose Mountain, but only one such leaf is known in the collections, and its preservation is not good enough to be sure of its identity.

\section{Leaves}

\section{Genus Trochodendron Siebold et Zuccarini, 1838}

\section{Trochodendron postnastae sp. nov.} Text-fig. $4 \mathrm{a}-\mathrm{f}, \mathrm{h}-\mathrm{j}$

H o lo ty p e. UCMP 201235 (Text-fig. 4a).

Plant Fossil Names Registry Number. PFN000103 (for new species).

Ety m o log y. This species is named in reference to the geologically older species, Trochodendron nastae, which it resembles except in having basally acrodromous rather than actinodromous veins.

Type locality. Moose Mountain flora near Cascadia, Oregon, USA.

Type horizon and age. Little Butte Volcanics Series, middle Miocene.

D i a g n o s is . Leaves with stout petioles and elliptical laminae, with length/width ratio 1.9 to $2.7: 1$. Base of lamina acute to almost right-angle and apex acute. Margin finely serrate in apical $2 / 3$ of lamina, entire with a fimbrial vein in the lower $1 / 3$. Venation pinnate with moderately thick midvein; basally acrodromous with a pair of strongly ascendant basal secondary veins plus 3 to 5 additional pairs of secondaries arising in the upper $2 / 3$ of the lamina. Secondaries arising at narrow angles from midvein, slightly curved, craspedodromous. Occasional agrophic/pectinal veins arising from the basal secondary veins. Intersecondary veins common. Tertiary and quaternary veins forming a quadrangular to polygonal mesh and with areoles having branched freely ending veinlets. Teeth simple, rounded to acute, glandular, principal vein entering upper side of tooth. Sinuses angular.

D i m e n s i on s. Petioles $1.8-2.3 \mathrm{~mm}$ thick, $12 \mathrm{~mm}$ to more than $15 \mathrm{~mm}$ long. Laminae $7.0-10.2 \mathrm{~cm}$ long, 2.6$5.3 \mathrm{~cm}$ wide, length/width ratio 1.9 to $2.7: 1$ with acute to almost right-angle base and acute apex. Secondaries arising at angles of $15-25^{\circ}$ from the midvein.

Remarks. These leaves resemble those of $T$. nastae from Republic but this new species has a pinnate acrodromous rather than actinodromous pattern. In other words, this species has only three strong veins radiating from near the base - the midvein and a pair of strong basal secondaries (Text-fig. 4a-e), whereas in T. nastae, three to five veins radiate from the base of the lamina giving an actinodromous/palmate aspect (Pigg et al. 2001: fig. 2A, 2B). Extant Trochodendron aralioides is characterized by rather coriaceous, evergreen leaves of variable morphology with long petioles, pinnate venation and a slightly crenulate margin with glandular teeth (Text-fig. 4g, k; Bailey and Nast 1945). Previously described Miocene leaves known from Kamchatka (T. evenense of Chelebaeva and Chigaeva 1988) are quite similar to extant leaves.

Although we cannot prove it, we deduce that $T$. postnastae leaves were likely borne on the plant which produced the infructescences of Trochodendron rosayi. This builds on a similar hypothesis that $T$. nastae leaves were produced by the same trees that yielded Trochodendron drachukii infructescences of the McAbee flora (Pigg et al. 2007). In both instances the leaves differ from those of extant Trochodendron, which has no tendency for actinodromous primaries or strong basal secondaries, but it is easy to imagine a transformational series from $T$. nastae (actinodromous) through $T$. postnastae (pinnate, basally acrodromous), to T. aralioides (simple pinnate). Aside from the difference in pattern of primary and basal secondary veins, the leaves of T. postnastae appear identical in architecture to the other fossil and modern Trochodendron leaves, as do leaves of T. nastae (Pigg et al. 2001). As yet, we have not confirmed Trochodendron foliage from the Emerald Creek and Sucker Creek localities. It would be nice to know whether they bore secondary veins in a normal pinnate manner or with an acrodromous or actinodromous pattern.

The observation that some geologically older Trochodendron leaves have more palmate, rather than pinnate venation, is consistent with this being a plesiomorphic feature within the clade that also includes Tetracentron with exclusively actinodromous venation. Tetracentron leaves are readily distinguished, in other characters; the leaves are deciduous and typically with a prominent cordate base and closely and evenly-spaced, distinctive "chloranthoid" teeth (sensu Hickey and Wolfe 1975). This proposed transition from actinodromous to pinnate venation is complicated, however, by the occurrence of both pinnate, and actinodromous trochodendraceous leaves in the Eocene Republic flora.

A single rather poorly preserved Trochodendron like leaf with a midvein and pinnate venation was found in the Moose Mountain assemblage (Text-fig. 4h). This is the kind of leaf we expect to associate with Concavistylon because of the physical attachment of such leaves on a twig bearing fruits of this genus from Republic, Washington (Manchester et al. in press; work in progress). This leaf type is also known from McAbee, where it was initially identified as Trochodendron (Pigg et al. 2007: fig. 7A-F); infructescences of both Trochodendron drachukii and Concavistylon sp. occur at McAbee.

\section{Biogeography}

Trochodendron and Tetracentron are both represented in the early Eocene of the Okanogan Highland region of Pacific Northwestern North America (Pigg et al. 2001, 2007), but are not confirmed from other continents at that time. By the Miocene, however, Trochodendraceae were apparently widespread in the Northern Hemisphere, with occurrences of Trochodendron confirmed by fruits from Kamchatka (Chelebaeva and Chigaeva 1988, Manchester et al. 2009: fig. 

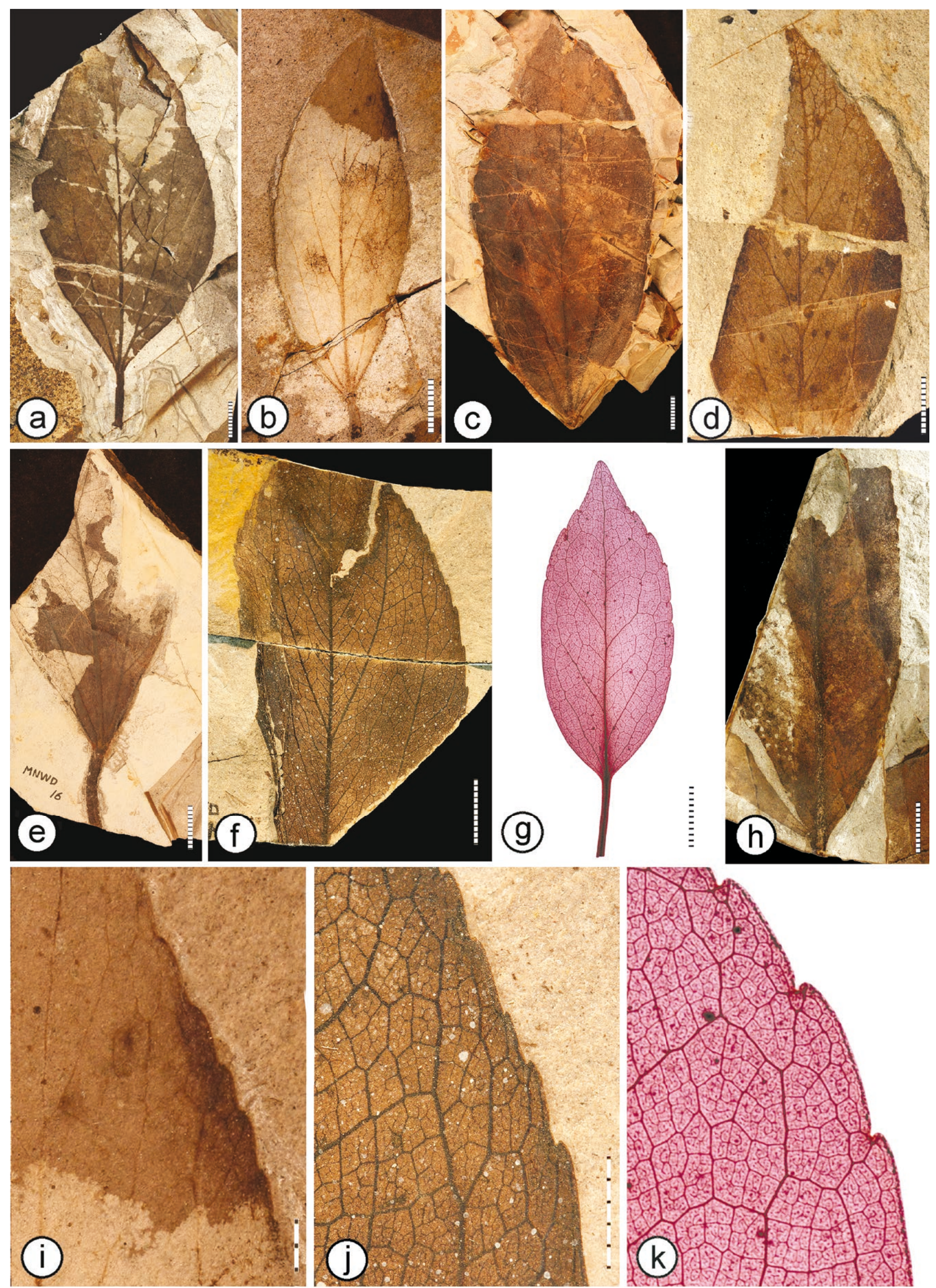

Text-fig. 4. Leaves of Trochodendraceae. a-f) Trochodendron postnastae from Moose Mountain flora, Oregon, hypothesized to be produced by the same species as fruits of $T$. rosayi. a) Leaf showing thick peduncle, basally acrodromous venation, holotype UCMP 201235. b) Narrow leaf with intact apex, UF 18110-70160. c) UF 18110-70156. d) UCMP 201237. e) UF 18110-70158. f) UF 18110-70157. g, k) Extant Trochodendron aralioides. h) Possible trochodendraceous leaf with simple pinnate venation, UCMP 201236. i, j) Details of margin and venation of $T$. postnastae enlarged from (b), (f). Scale bars calibrated in $\mathrm{mm}$. 
57) and Japan (Manchester et al. 1991: figs 30, 33), as well as Pacific northwestern North America, and Tetracentron is known both from Idaho (Manchester and Chen 2006) and Iceland (Grímsson et al. 2008).

\section{Paleoecology}

At most Neogene sites, the fossils of Trochodendraceae are relatively rare. Only one specimen of Trochodendron is known from the Emerald Creek site (Text-fig. 2d) and just one from Sucker Creek (Fields 1996a, b); similarly, only a single specimen of Tetracentron was collected from Clarkia (Manchester and Chen 2006), despite many years of collecting at these sites. This suggests that Trochodendraceae were only an accessory element rather than a dominant element of the lakeside vegetation represented in these deposits. At Moose Mountain, however, several infructescences have been recovered and the leaves of $T$. postnastae are relatively common.

Other elements of the Moose Mountain flora listed by Jack Wolfe (in Peck et al. 1964, for USGS locality 9350) include Metasequoia Miki, Sequoia EndL., Betula L., Pterocarya NutT., Quercus L., Sassafras J.PresL, Exbucklandia R.W.Br., Acer L., and Arbutus L. Among the collections from this locality at UCMP, we also observed leaves of Platanus L. and Tilia L. and an infructescence of Alnus Mill. Acer is represented by A. cascadense Wolfe et TANAI samaras and leaves of $A$. smiley $i$ Wolfe et TANAI and $A$. oregonianum Wolfe et TANAi (Wolfe and Tanai 1987). These elements are interpreted as representing a mixed hardwood temperate deciduous forest. An extinct genus, Ozakia, also occurs there, which was disjunctly distributed with occurrences in mesophytic Miocene floras of Japan, Oregon and Idaho (Manchester and Uemura 2013). Although most elements of the Moose Mountain flora are deciduous, extant Trochodendron is evergreen, and it may be reasonable to expect that $T$. postnastae, with its relatively thick petiole, may have been so as well.

\section{Trochodendraceous diversity}

The two infructescence types described herein from the Moose Mountain flora near Cascadia, Oregon, are similar to one another in general structure and we consider both to be assignable to Trochodendraceae. However, they differ markedly from one another in several significant features. Trochodendron rosayi has relatively large fruits (7.5$10 \mathrm{~mm}$ long) with elongate pedicels, as is typical of other species of fossil and extant Trochodendron. Concavistylon kvacekii infructescences bear smaller fruits (3-4 mm long) that are sessile to shortly pedicellate. Fruits of $T$. rosayi are comparable in size to fruits of extant $T$. aralioides (Textfig. $2 \mathrm{e}-\mathrm{g}$ ), but are more than twice as large as Paleogene $T$. drachuckii fruits (3-4 mm long). Concavistylon has 4 to 6 styles in comparison to about 10 in $T$. rosayi, which is more similar to extant $T$. aralioides which typically bears 7-9 styles. Most notably, Concavistylon bears styles that curve upward (concavely) toward the fruiting axis rather than away from it as do those of the Miocene and extant species of both Trochodendron and Tetracentron.
We now know more about the trochodendraceous leaves as well. Extant Trochodendron aralioides is characterized by rather coriaceous, evergreen leaves of variable morphology with pinnate venation and a slightly crenulate margin with glandular teeth (Bailey and Nast 1945). Previously described Miocene leaves from Kamchatka (T. evenense of Chelebaeva and Chigaeva 1988) are quite similar to extant leaves. In contrast, two types of Trochodendron leaves are known from the Eocene Okanogan Highlands floras: those of T. nastae (Pigg et al. 2001) and a second type that has been found in organic connection to a twig bearing a Concavistylon-type infructescence. Leaves of $T$. nastae have basally palmate, rather than pinnate venation, but otherwise appear identical in architecture to modern and other fossil Trochodendron leaves (Pigg et al. 2001). Leaves from Republic found in attachment to a second type of Concavistylon infructesence, and similar leaves from McAbee, are relatively large (up to $12.7 \mathrm{~cm}$ long) and have standard pinnate venation like that of extant Trochodendron (Pigg et al. 2007: fig. 4D). We suggest that in the Eocene T. nastae leaves may have been produced by the same plants as the fruits of $T$. drachukii, whereas $T$. postnastae may be the leaf type formed by plants that bore $T$. rosayi infructesences.

In this contribution we have shown that the fossil record of Trochodendraceae was more diverse in Miocene than previously known. The newly described Trochodendron rosayi has infructesences with "typical" features of modern Trochodendron such as outcurved styles, pedicellate fruits, flattened triangular nectaries, and numerous stamen scars like the extant $T$. aralioides. However, we have also documented an infructescence type and a leaf type that differ from previously known taxa. Concavistylon has sessile to shortpedicelled fruits, and smaller number of styles that curve upwards toward the shoot rather than outwards as is typical of Trochodendron. This feature appears to be plastic in Eocene fruits. It is striking that this aspect of style structure is present in even young developing fruits of extant Trochodendron (Hsu et al. 2017: fig. 9E). As we learn more about the diversity of trochodendracous plants in the fossil record, we hope to better understand the evolutionary history, biogeography and phylogenetic relationships of this intriguing family.

\section{Acknowledgements}

We thank Robert Rosé for granting permission to cite the radiometric date that he commissioned, for providing access to his fossil plant collection representing many years of dedicated field work, and for donating selected specimens cited in this article. Diane Erwin provided access to specimens at the University of California Museum of Paleontology. Robert Duncan, Zlatko Kvaček, Walter Judd, and Greg Retallack provided helpful discussion. We thank Bruce Tiffney and Friðger Grímsson for helpful review comments. This work was supported in part by NSF grant EAR1338285.

\section{References}

Bailey, I. W., Nast, C. G. (1945): Morphology and relationships of Trochodendron and Tetracentron. Stem, root and leaf. - Journal of the Arnold Arboretum, 26: 143-154. 
Chelebaeva, A. L., Chigaeva, G. B. (1988): [The genus Trochodendron (Trochodendraceae) in the Miocene of Kamchatka]. - Botanicheskiy Zhurnal, 73: 315-318. (in Russian with English summary)

Crane, P. R., Manchester, S. R., Dilcher, D. L. (1991): Reproductive and vegetative structure of Nordenskioldia (Trochodendraceae), a vesselless dicotyledon from the Early Tertiary of the Northern Hemisphere. - American Journal of Botany, 78: 1311-1334. https://doi.org/10.1002/j.1537-2197.1991.tb12599.x

Denk, T., Grímsson, F., Zetter, R., Símonarson, L. A. (2011): Late Cainozoic floras of Iceland. 15 Million years of vegetation and climate history in the Northern North Atlantic. - Springer Verlag, Berlin, 854 pp. https://doi.org/10.1007/978-94-007-0372-8

Doweld, A. B. (1998): Carpology, seed anatomy and taxonomic relationships of Tetracentron (Tetracentraceae) and Trochodendron (Trochodendraceae). - Annals of Botany, 82: 413-443. https://doi.org/10.1006/anbo.1998.0679

Endress, P. K. (1986). Floral Structure, Systematics, and Phylogeny in Trochodendrales. - Annals of the Missouri Botanical Garden, 73: 297-324. https://doi.org/10.2307/2399115

Fields, P. F. (1996a): The Succor Creek flora of the middle Miocene Sucker Creek Formation, southwestern Idaho and eastern Oregon: Systematics and paleoecology; $\mathrm{PhD}$ dissertation. - MS, Michigan State University, Lansing, USA, 675 pp. (copy in library of Michigan State University)

Fields, P. F. (1996b): A Trochodendron infructescence from the $15 \mathrm{Ma}$ Succor Creek flora in Oregon: a geographic and possibly temporal range extension. - American Journal of Botany, 83(Suppl): 110.

Greenwood, D. R., Pigg, K. B., Basinger, J. F., DeVore, M. L. (2016): A review of paleobotanical studies of the early Eocene Okanagan (Okanogan) Highlands floras of British Columbia, Canada and Washington, USA. - Canadian Journal of Earth Sciences, 53: 548-564. https://oi.org/10.1139/cjes-2015-0177

Grímsson, F., Denk, T., Zetter, R. (2008): Pollen, fruits, and leaves of Tetracentron (Trochodendraceae) from the Cainozoic of Iceland and western North America and their palaeobiogeographic implications. - Grana, 47(1): 1-14. https://doi.org/10.1080/00173130701873081

Grímsson, F., Meller, B., Bouchal, J. M., Zetter, R. (2015): Combined LM and SEM study of the middle Miocene (Sarmatian) palynoflora from the Lavanttal Basin, Austria: part III. Magnoliophyta 1-Magnoliales to Fabales. - Grana, 54(2): 85-128. https://doi.org/10.1080/00173134.2015.1007081

Hergert, H. L., Phinney, H. K. (1954): Trochodendroxylon beckii gen. et sp. nov. from the Tertiary of Oregon. - Bulletin of the Torrey Botanical Club, 81: 118-122. https://doi.org/10.2307/2481846

Hickey, L. J. (1973): Classification of the architecture of dicotyledonous leaves. - American Journal of Botany, 60: $17-33$.

https://doi.org/10.1002/j.1537-2197.1973.tb10192.x
Hickey, L. J., Wolfe, J. A. (1975): The bases of angiosperm phylogeny: vegetative morphology. - Annals of the Missouri Botanical Garden, 62(3): 538-589. https://doi.org/10.2307/2395267

Hsu,Y.-C., Jane, W.-N., Chen, S.-H. (2017): Inflorescence and floral development in Trochodendron aralioides (Trochodendraceae). - Plant Systematics and Evolution, 303: 403-412. https://doi.org/10.1007/s00606-016-1379-2

Judd, W. S., Campbell, C. S., Kellog, E. A., Stevens, P. F., Donoghue, M. J. (2007): Plant systematics: a phylogenetic approach (3rd edition). - Sinauer Associates, Sunderland, Massachusetts, $620 \mathrm{pp}$.

Manchester, S. R., Chen, I. (2006): Tetracentron fruits from the Miocene of western North America. - International Journal of Plant Sciences, 167(3): 601-605. https://doi.org/10.1086/503206

Manchester, S. R, Chen, Z.-D., Lu, A.-M., Uemura, K. (2009): Eastern Asian endemic seed plant genera and their paleogeographic history throughout the Northern Hemisphere. - Journal of Systematics and Evolution, 47(1): 1-42. https://doi.org/10.1111/j.1759-6831.2009.00001.x

Manchester, S. R., Crane, P. R., Dilcher, D. L. (1991): Nordenskioldia and Trochodendron fruits (Trochodendraceae) from the Miocene of northwestern North America. - Botanical Gazette, 152: 357-368. https://doi.org/10.1086/337898

Manchester, S. R., Pigg, K. B., DeVore, M. L., Kvaček, Z., Dillhoff, R. M. (2017): Extinct character combinations in Trochodendraceae from the Eocene of Washington and British Columbia. - Botany 2017 Abstracts, Fort Worth, TX, June 2017.

Manchester, S. R., Pigg, K. B., Kvaček, Z., DeVore, M. L., Dillhoff, R. M. (in press): Newly recognized diversity in Trochodendraceae from the Eocene of western North America. - International Journal of Plant Sciences.

Manchester, S. R., Uemura, K. (2013): Ozakia, a new genus of winged fruit shared between the Miocene of Japan and western North America. - Journal of Plant Research, 127(2): 187-92. https://doi.org/10.1007/s10265-013-0602-2

Ozaki, K. (1987): Tetracentron leaves from the Neogene of Japan. - Transactions and Proceedings of the Palaeontological Society of Japan, New Series, 146: 77-87.

Peck, D. L., Griggs, A. B., Schlicker, H. G., Well, F. G., Dole, H. M. (1964): Geology of the central and northern parts of the Western Cascade Range in Oregon. - U.S. Geological Survey Professional Paper, 449: 1-56.

Pigg, K. B., Dillhoff, R. M., DeVore, M. L., Wehr, W. C. (2007): New diversity among the Trochodendraceae from the early/middle Eocene Okanogan Highlands of British Columbia, Canada, and northeastern Washington State, United States. - International Journal of Plant Sciences, 168: 521-532. https://doi.org/10.1086/512104

Pigg, K. B., Wehr, W. C. (2002): Tertiary flowers, fruits, and seeds of Washington State and adjacent areas - Part III. - Washington Geology, 30(3/4): 3-16. 
Pigg, K. B., Wehr, W. C., Ickert-Bond, S. M. (2001): Trochodendron and Nordenskioldia (Trochodendraceae) from the middle Eocene of Washington State, USA. - International Journal of Plant Sciences, 162: 1187-1198. https://doi.org/10.1086/321927

Suzuki, K. (1967): Discovery of Tetracentron leaves from the Neogene in Japan. - Proceedings of the Japanese Academy, 43: 526-530.

Tanai, T. (1961): Neogene floral change in Japan. - Journal of the Faculty of Science, Hokkaido University, Series 4, Geology and mineralogy, 11(2): 119-398.
Uemura, K. (1988): Late Miocene floras of northeast Honshu, Japan. - Bulletin of the Natural Science Museum Tokyo, 14: 1-196.

Wolfe, J. A., Tanai, T. (1987): Systematics, phylogeny, and distribution of Acer (maples) in the Cenozoic of western North America. - Journal of the Faculty of Science, Hokkaido University, Series 4, Geology and mineralogy, 22(1): 1-246. 